\title{
Dark spot syndrome: recent or old?
}

Received: 12 January 2007 / Accepted: 21 January 2007 / Published online: 27 February 2007

C) Springer-Verlag 2007

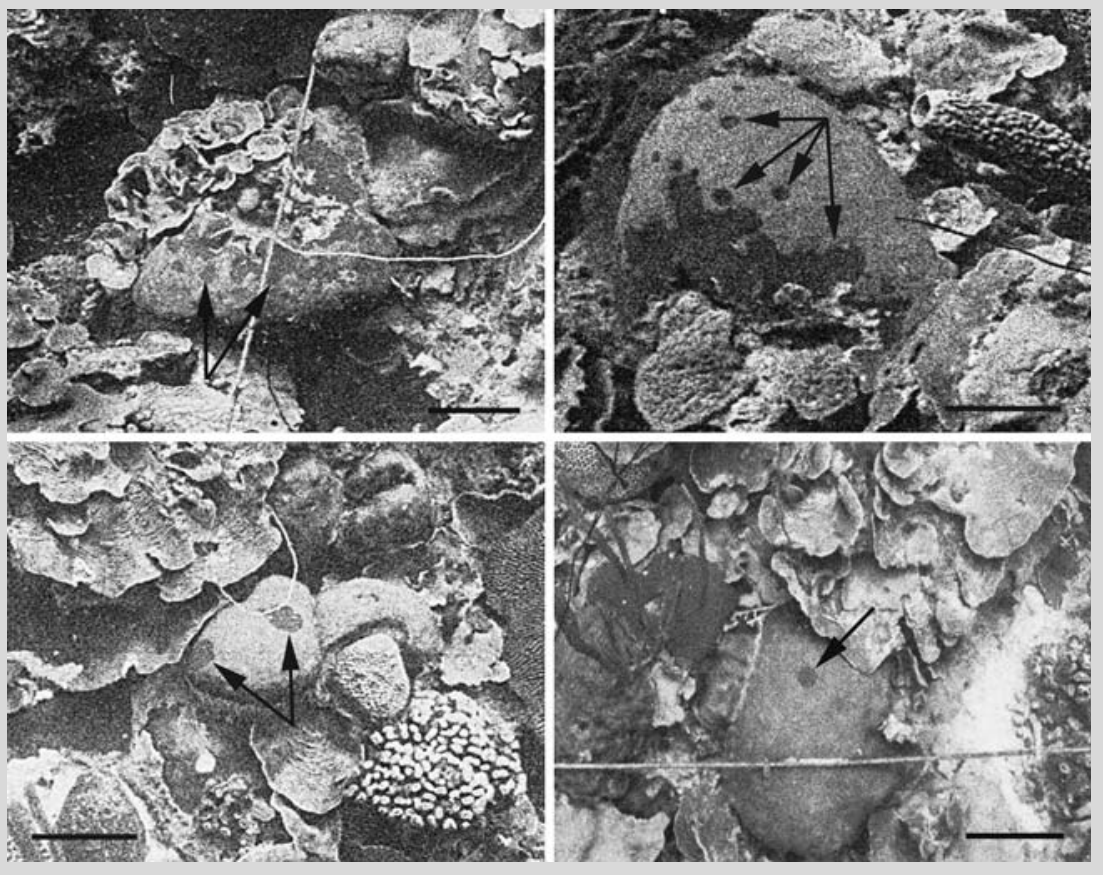

Fig. 1 Apparent dark spot syndrome on Stephanocoenia colonies at $20( \pm 3) \mathrm{m}$ depth in Bonaire, Netherlands Antilles, 27 September 1974. Arrows show location of darkened tissue areas characteristic of the syndrome. Scale bars $=20 \mathrm{~cm}$
Dark spot syndrome, also called dark spots disease, was first reported in 1990 in the Rosario islands off the Colombian coast (Solano et al. 1993). Since then it has been observed throughout the Caribbean, affecting primarily the species Stephanocoenia michelinii, Sidereastrea siderea and Montastraea annularis (Gil-Agudelo et al. 2004). The syndrome is characterized by darkened areas in the middle of normal tissue and/or along coral margins. These areas may expand over time and form a depression in the coral skeleton, with subsequent tissue necrosis and colonization by algae. Causal pathogen(s) are yet to be identified.

In Bonaire, dark spot syndrome was first observed in 1997 (T. J. Goreau, personal communication) and has remained widespread since. However, it may have been present for longer time periods. What appears to be dark spot syndrome has been observed on several $S$. michelinii colonies from

black and white photographs taken in 1974 in Bonaire (Fig. 1). This observation suggests that dark spot syndrome may have been present on coral reefs at least 23 years before its first sighting in Bonaire and 16 years before its first published report in the Caribbean.

Many diseases or syndromes may have occurred on coral reefs long before the multiplication of "new" disease reports during the 1990s. At that time they may have been classified as mortality rather than disease, misidentified as another disease, or simply have gone unnoticed. The relatively old occurrence of several coral diseases suggests that pathogens were present on reefs well before diseases became widespread. This emphasizes the importance of lowered coral resistance and increased pathogen virulence, as opposed to the introduction of new pathogens in the recent spread of coral diseases.

\section{References}

Gil-Agudelo DL, Smith GW, Garzón-Ferreira J, Weil E, Petersen D (2004) Dark spots disease and yellow band disease, two poorly known coral diseases with high incidence in Caribbean reefs. In: Rosenberg E, Loya Y (eds) Coral health and disease. Springer, Berlin, pp 337-350

Solano OD, Navas-Suarez G, Moreno-Forero SK (1993) Blanqueamiento coralino de 1990 en el Parque Nacional Natural Corales del Rosario (Caribe colombiano). An Inst Invest Mar Punta de Betín 22:97-111

M. M. Nugues $(\varangle)$. R. P. M. Bak

Royal Netherlands Institute for Sea Research (NIOZ), P.O. Box 59, 1790 AB Den Burg, Texel, The Netherlands e-mail: mnugues@nioz.nl

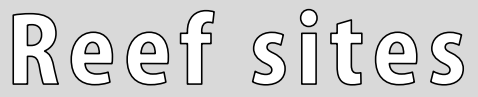

Coral Reefs (2007) 26:359

DOI $10.1007 / \mathrm{s} 00338-007-0201-6$ 